\title{
INTELLIGENCE INSIDE THE KING'S COLLEGE OF CAMBRIDGE
}

\author{
Henriono Nugroho \\ Jurusan Sastra Inggris Universitas Jember, Jl. Kalimantan 37 Jember, Jawa Timur \\ h-nugroho@hotmail.com
}

\begin{abstract}
Article concerns with a stylistic analysis on a poem in terms of Systemic Functional Linguistics and Verbal Art Semiotics. The writing uses library research, qualitative data, documentary study, descriptive method and intrinsic-objective approach. The semantic analysis results in both automatized and foregrounded meanings. Then the automatized meaning produces lexical cohesion and in turn, it produces subject matter. Meanwhile, the foregrounded meaning produces the literary meaning and in turn, it creates theme. Finally, the analysis indicates that the subject matter is about the establishment of Cambridge University, the literary meaning is about eternal thoughts of Cambridge University, and the theme is about intelligence.
\end{abstract}

Keywords: semantic, automatized meaning, foregrounded meaning, theme

\begin{abstract}
ABSTRAK
Penelitian mengkaji karya sastra melalui analisis stilistik berdasarkan ilmu bahasa sistemik fungsional dan sistem semiotik karya sastra. Metode penelitian menggunakan studi pustaka, metode deskriptif dan pendekatan intrinsik objektif. Hasil penelitian menunjukkan bahwa analisis semantik menghasilkan makna bahasa latar belakang (the automatized linguistic meaning) dan makna bahasa latar depan (the foregrounded linguistic meaning). Kemudian makna pertama menghasilkan masalah utama (subject matter) dan makna kedua menghasilkan makna sastra (literary meaning). Selanjutnya makna sastra menghasilkan tema. Akhirnya terbukti bahwa masalah utama berkisah tentang pendirian Universitas Cambridge dan makna sastra tentang gagasan kekal Universitas Cambridge serta tema tentang inteligensia.
\end{abstract}

Kata kunci: semantik, makna bahasa latar belakang, makna bahasa latar depan, tema 


\section{INTRODUCTION}

Generally, there are several theories of stylistics namely formal, functional, feminine, pragmatic, affective, cognitive, pedagogical and critical (Webber, 1996). Particularly the functional stylistics includes Functionalism, Systemic Functionalism, Tagmemics, Prague School Functionalism and West Coast Functionalism (Matthiessen, 1995). Based on Systemic Functional Linguistics, language can be ordered in contexts with cline of instantiation (actualization over time): context of culture and language, situation types and registers, situations and texts, and situation and text (Halliday \& Matthiessen, 1999). According to Halliday and Matthiessen (1999), context of culture (cultural context) concerns with meaning potential (overall meaning), and context of situation (situational context) deals with the actualization of meaning potential (actualized meaning potential). Meanwhile, Kluckhohn (1953) claims that culture (cultural context) refers to notions, values and norms, whereas the domain of socio-cultural context corresponds to universal categories such as language, art, science, technology, economy, social organization and religion. The language order is outlined in Figure 1.
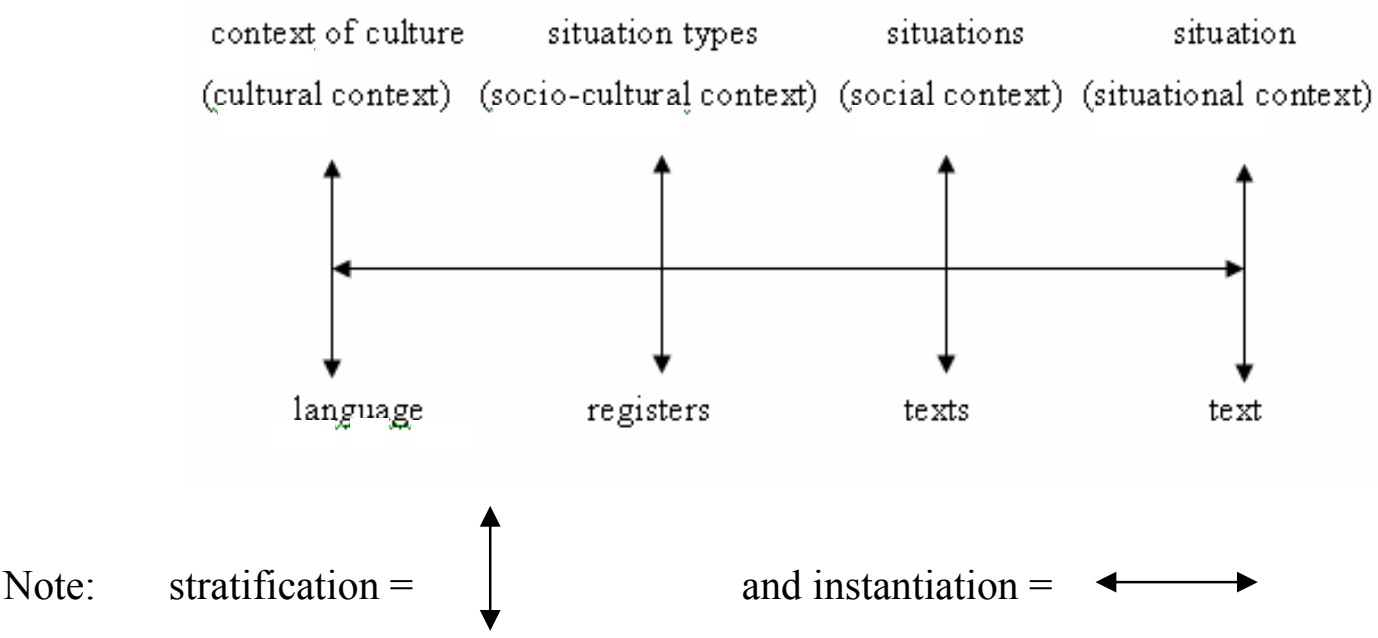

Fig. 1 The Interrelatedness of Context, Language, Situation and Text

A text is a semantic unit and a clause is a grammatical unit (Halliday, 1994). Whereas, semantics is an interface between context of situation and lexicogrammar; in this sense the semantic systems are related "upward" to contextual systems and they are related "downward" to lexicogrammatical systems (Halliday, 1993). The contextual systems are Field, Tenor and Mode. The semantic systems are Ideational, Interpersonal and Textual Meanings. The lexicogrammatical systems are Complexing, Transitivity, Mood and Theme. In addition, the semantic systems are related "sideways" to discoursal systems (Eggins, 1994). The discoursal systems are structural conjunction, lexical cohesion, conversational structure and grammatical cohesion. The interrelationship of situation, discourse, semantics and lexicogrammar is diagrammed in Table 1. 
Table 1 The Relation of Context, Text and Clause

\begin{tabular}{|c|c|c|c|c|c|}
\hline ن & Situation & \multicolumn{2}{|c|}{$\begin{array}{c}\text { Field } \\
\text { Subject Matter }\end{array}$} & $\begin{array}{c}\text { Tenor } \\
\text { Role Relation }\end{array}$ & $\begin{array}{c}\text { Mode } \\
\text { Rhetoric }\end{array}$ \\
\hline \multirow{2}{*}{$\stackrel{\vec{x}}{\stackrel{\vec{x}}{\mid}}$} & Discourse & $\begin{array}{c}\text { Structural } \\
\text { Conjunction }\end{array}$ & $\begin{array}{l}\text { ** Lexical } \\
\text { Cohesion }\end{array}$ & $\begin{array}{c}\text { Conversational } \\
\text { Structure }\end{array}$ & $\begin{array}{c}\text { * Grammatical } \\
\text { Cohesion }\end{array}$ \\
\hline & Semantics & $\begin{array}{l}\text { \# Logical } \\
\text { Meaning }\end{array}$ & $\begin{array}{c}\text { \# Experiential } \\
\text { Meaning }\end{array}$ & $\begin{array}{c}\text { Interpersonal } \\
\text { Meaning }\end{array}$ & $\begin{array}{l}\text { Textual } \\
\text { Meaning }\end{array}$ \\
\hline$\frac{\mathscr{\omega}}{\mathrm{E}}$ & Lexicogrammar & Complexing & Transitivity & *** Mood & Theme \\
\hline
\end{tabular}

Note: \# Logical Meaning \& Experiential Meaning = Ideational Meaning

* Including Reference, Substitution, Ellipsis and Cohesive Conjunction

** Including Reiteration \& Collocation

*** Including Polarity and Modality

Literariness is defined as the difference between automatization or background and defamiliarization or foreground (Jefferson, 1995: 37). Background is also called ground, automatization, familiarization, and the normal, habitual, canonical, common, automatized or familiarizing pattern, whereas foreground(ing) is also called figure, deautomatization, defamiliarization, and the foregrounded, motivated, prominent, dominant, deautomatized or defamiliarizing pattern (Jefferson 1995, Hasan 1985, Halliday 1971). Meanwhile, the concept of background and foreground is used by Hasan (1985: 99) to propose the semiotic system of verbal art. The verbal art semiotics deals with verbalization, symbolic articulation and theme, and verbalization itself is the semiotic system of language concerned with phonology, lexicogrammar and semantics. Especially, Verbalization - the lowest stratum - is where the point of primary contact with work reveals the meaning of language (the deep level of meaning). Symbolic articulation - the middle stratum - is where the deep level of meaning functions as a sign, symbol or metaphor for the deeper level of meaning. Finally, Theme - the highest stratum is where the deeper level of meaning creates the deepest level of meaning as follows.

This article is concerned with a systemic stylistic analysis on a poem of William Wordsworth

Inside of King's College Chapel, Cambridge

Thou not tax the royal saint with vain expense

With ill-matched aims the Architect planned Albeit he laboured for a scanty band

Of white-robed scholars only; this immense And glorious work for fine intelligence

Give thou can; high Heaven rejects the lore Of nicely-calculated less or more.

So deemed the man, who fashioned for the sense Those lofty pillars, to notice that branching roof Self poised and scooped into ten thousand cells; There light and shape repose, and music dwells, Lingering and wandering towards mortality; Thoughts yieldth the very sweetness of proof, That they were born for eternity. 


\section{The Semiotic System of Language}

\section{Logical Meaning, Logical Metafunction or Logical Semantics}

Logical meaning is a resource for constructing logical relation (Halliday, 1994: 36) and the logical meaning describes a clause type (clause complex). In fact, the poem is realized by 2 clause complexes consisting of 2 main clauses and 13 expanding clauses. Out of 13 expanding clauses, there are 7 extending paratactic clauses, 3 elaborating hypotactic clauses, 1 enhancing hypotactic clause and 2 embedded clauses. Thus, extension is the automatized pattern because the poem is frequently realized by extending clauses. Then, logical meaning is realized by complexing, and the complexing analysis is presented in Table 2 .

Table 2 Complexing Analysis

\begin{tabular}{|c|c|c|c|}
\hline No. & Notation & Logical Relation & Clause \\
\hline 1. & 1 & Main clause & $\begin{array}{l}\text { Thou do not tax the royal saint with vain expense and ill-matched aims } \\
{[[1.1 \| 1.2]]}\end{array}$ \\
\hline 1.1 & {$[[]]$} & Embedding & the Architect planned \\
\hline 1.2 & {$[[\quad]]$} & Embedding & albeit he labored for a scanty band of white robed scholars only; \\
\hline 2. & ${ }^{+} 2$ & Extension & Thou can give this immense and glorious work of fine intelligence; \\
\hline 3. & ${ }^{+} 3$ & Extension & high Heaven rejects the lore of nicely-calculated less or more. \\
\hline 4. & $1 \alpha$ & Main clause & The man so deemed $<<5>>$, to notice that branching roof \\
\hline 5. & $1 \alpha=\beta$ & Elaboration & Who fashioned these lofty pillars for the sense \\
\hline 6. & $1=\beta 1$ & Elaboration & which is self-poised \\
\hline 7. & $1=\beta 2$ & Elaboration & and which is scooped into ten thousand cells; \\
\hline 8. & ${ }^{+} 2$ & Extension & There light and shade repose \\
\hline 9. & ${ }^{+} 3$ & Extension & and music dwells \\
\hline 10. & ${ }^{+} 4$ & Extension & Lingering \\
\hline 11. & ${ }^{+} 5$ & Extension & and wandering towards mortality \\
\hline 12. & ${ }^{+} 6 \alpha$ & Extension & thoughts yieldeth the very sweetness of proof \\
\hline 13. & $6^{x_{\beta}}$ & Enhancement & so that they were born for eternity. \\
\hline
\end{tabular}

\section{Experiential Meaning, Experiential Metafunction or Experiential Semantics}

Experiential meaning is a resource for construing experience (Halliday, 1994: 36) and the experiential meaning discusses a process type (processes). Actually, the poem is encoded by 12 clauses of material process, 3 clauses of mental process and 1 clause of relational process. The poem is also encoded by 7 clauses of present tense and 6 clauses of past tense. Furthermore, the poem is construed by 13 clauses of finiteness and 2 clauses of non-finiteness. Consequently, material process, present tense and finiteness are the automatized patterns, because they are frequently used in the poem. Then, experiential meaning is encoded by transitivity, and the transitivity analysis is displayed in Table 3. 
Table 3 Transitivity Analysis

\begin{tabular}{ccccc}
\hline No. & Process & Tense & Finiteness & Verbal Group \\
\hline 1. & Material & Present & - & do not tax \\
1.1 & Material & Past & - & planned \\
1.2 & Material & Past & - & labored \\
2. & Material & Present & - & can give \\
3. & Material & Present & - & rejects \\
4. & Mental & Past & - & deemed to notice \\
5. & Material & Past & - & fashioned \\
6. & Material & Present & - & is self-poised \\
7. & Material & Present & - & is scooped \\
8. & Material & Present & - & repose \\
9. & Material & Present & - & dwells \\
10. & Material & - & Non-finite & lingering \\
11. & Material & - & Non-finite & wandering \\
12. & Mental & Past & - & yieldeth \\
13. & Relational & Past & - & were born \\
\hline
\end{tabular}

\section{Lexical Cohesion}

A poem is realized by several lexical chains and each chain consists of a number of lexical items. The poem is realized by 8 lexical chains consisting of 40 lexical items. The lexical chains include thou (3), Architect (2), material process (12), mental process (3), synonym (12), antonym (6), and comeronym (2). In other words, the poem is frequently realized by the main lexical chains of thou, material process and synonym and the lexical cohesion is shown in Table 4.

Table 4 Lexical Cohesion

\begin{tabular}{|c|c|c|c|}
\hline No. & Lexical Chain & Lexical Item & Total \\
\hline 1. & Thou & Thou, thou, the man & 3 \\
\hline 2. & Architect & Architect, he & 2 \\
\hline 3. & Material Process & $\begin{array}{l}\text { tax, planned, labored, give, rejects fashioned, scooped, reposed, } \\
\text { dwells, lingering, wandering, self-poised }\end{array}$ & 12 \\
\hline 4. & Mental Process & deemed, yieldeth (impressed) & 2 \\
\hline 5. & Relational Process & were & 1 \\
\hline 6. & Synonym & $\begin{array}{l}\text { royal }=\text { lofty, vain }=\text { ill, immense }=\text { glorious, fine }=\text { sweetness, } \\
\text { intelligence }=\text { lore, } \text { sense }=\text { thoughts }\end{array}$ & 12 \\
\hline 7. & Antonym & less $><$ more, light $><$ shade, immortality $><$ eternity & 6 \\
\hline 8. & Comeronym & roof - pillars & 2 \\
\hline
\end{tabular}




\section{Subject Matter}

Halliday (1993: 110) states that Field includes subject matter as one special manifestation and Halliday (1993: 143) claims that Field is realized by Experiential Meaning. Then, Eggins (1994: 113) explains that Field is encoded by Experiential Meaning and lexical cohesion. In addition, Butt (1988: 177) describes that subject matter is expressed by lexical chains and specifically subject matter is indicated by the main lexical chains (Butt, 1988: 182). Thus, subject matter is realized by Experiential Meaning and lexical cohesion (lexical chains).

In section 2.2, experiential meaning is frequently realized by material process. In section 2.4 , lexical cohesion is frequently realized by material process. In other words, subject matter is frequently realized by material process. In fact, the analysis of material processes indicates that the functional elements are Actor (Thou), Material Process (worked for) and Goal (Cambridge University). In short, the subject matter reveals that thou worked for Cambridge University. The analysis of relational process is illustrated in Table 5 .

Table 5: The Analysis of Relational Process

\begin{tabular}{ccccc} 
No. & Actor & Process & Goal & Circumstance \\
\hline 1. & Thou & do not tax & the royal saint & $\begin{array}{c}\text { with vain expense and ill- } \\
\text { matched aims }\end{array}$ \\
2. & Thou & can give & $\begin{array}{c}\text { this immense and glorious } \\
\text { work of fine intelligence }\end{array}$ & \\
3. & The man & deemed to notice & the branching roof & for the sense \\
4. & The man & Fashioned & these lofty pillars & \\
5. & Architect & Planned & & for a scanty band of \\
6. & Architect & Labored & & scholars only \\
\hline
\end{tabular}

\section{Logogenetic Process}

According to Halliday and Matthiessen (1998: 184-5), logogenesis is a process of making meaning through an instantial system (a changing system) when text unfolds (in the unfolding text). The speaker/writer uses the instantial system (the changing system) as a resource to create a text, whereas the listener/reader uses the instantial system (the changing system) as a resource to interpret the text. Moreover, Matthiessen (1995: 40) adds that logogenetic process reveals that lexicogrammatical shift (Cf. Butt, 1988: 83 on "latent patterning") coincides with episodic shift (Hasan, 1988: 60 on "textual structure"). Textual structure is also called narrative structure (O'Toole, 1983), schematic structure (Martin, 1985), staging structure (Plum, 1988) and generic structure (Eggins, 1994). In this poem, shifts (changes) are described as follows:

Shift from present tense (clause 3) to past tense (clause 4) coincides with shift from the fine intelligence of Cambridge University to the eternal thoughts of Cambridge University.

Thus, the changing system of process and tense is used to make meanings, and the logogenetic process is outlined in Table 6 . 
Table 6 Logogenetic Process

\begin{tabular}{ccc}
\hline $\begin{array}{c}\text { Clause } \\
\text { Number }\end{array}$ & $\begin{array}{c}\text { Lexicogrammatical Shift } \\
\text { Cf. Latent Patterning }\end{array}$ & $\begin{array}{c}\text { Episodic Shift } \\
\text { Cf. Textual Structure }\end{array}$ \\
\hline 1 & Present Tense & The Fine Intelligence of \\
3 & Present Tense & Cambridge University \\
4 & Past Tense & The Eternal Thoughts of \\
13 & Past Tense & Cambridge University \\
\hline
\end{tabular}

\section{DISCUSSION}

\section{The Semiotic System of Verbal Art}

Verbalization: The Deep Level of Meaning

In section 2.1, extension is automatized, so a combination of elaboration, extension and enhancement is foregrounded. Thus, the foregrounding of logical relation takes place in clauses $4,5,6,7,8,9,10$, 11,12 and 13. In section 2.2, material process is automatized, so other processes are foregrounded. Therefore, the foregrounding of process occurs in clauses 4, 12 and 13. Moreover, present tense is automatized, so past tense is foregrounded. Consequently, the foregrounding of tense exists in clauses $2,3,4,5,12$ and 13. Furthermore, finiteness is automatized, so non-finiteness is foregrounded. Accordingly, the foregrounding of non-finiteness exists in clauses 10 and 11. Finally, patterns of foregrounding are mapped out in Table 7.

Table 7 Patterns of Foregrounding

\begin{tabular}{ccccc}
\hline No. & Logical Relation & Process & Tense & Non-finiteness \\
\hline 1. & - & - & - & - \\
1.1 & - & - & $\mathrm{x}$ & - \\
1.2 & - & - & $\mathrm{x}$ & - \\
2. & - & - & - & - \\
3. & - & $\mathrm{X}$ & $\mathrm{x}$ & - \\
4. & $\mathrm{x}$ & - & $\mathrm{x}$ & - \\
5. & $\mathrm{x}$ & - & - & - \\
6. & $\mathrm{x}$ & - & - & $\mathrm{x}$ \\
7. & $\mathrm{x}$ & - & - & - \\
8. & $\mathrm{x}$ & $\mathrm{x}$ & $\mathrm{x}$ & - \\
9. & $\mathrm{x}$ & $\mathrm{x}$ & $\mathrm{x}$ & \\
10. & $\mathrm{x}$ & & & \\
11. & & & & \\
& & & & \\
\hline
\end{tabular}

Note: dotted line $=$ clause complex boundaries

Table 7 above shows that patterning of the various foregrounded patterns point toward clauses $4,5,6,7,8,9,10,11,12$ and 13 . In other words, consistency of foregrounding converges toward the last clause complex because of logical relation, process, tense and non-finiteness. Then, the consistency of foregrounding makes the foregrounded patterns of the last clause complex produce consistently foregrounded meaning which is also called the deep level of meaning and the first order 
meaning. In brief, the consistently foregrounded meaning is called the deep level of meaning, which can be seen in: The man, who fashioned for the sense those lofty pillars, to notice that branching roof self poised and scooped into ten thousand cells; there light and shape repose, and music dwells, lingering and wandering towards mortality; thoughts yieldth the very sweetness of proof, that they were born for eternity.

\section{Symbolic Articulation: The Deeper Level of Meaning}

The deep level of meaning functions as the sign, symbol or metaphor of the deep level of meaning which is also called the second order meaning and literary meaning. In section 3.1, the deep level of meaning refers to the last clause complex because of the foregrounding of logical relation (a combination of elaboration, extension and enhancement), process (mental and relational), tense (past tense) and non-finiteness (lingering and wandering). Then, the last clause complex describes that the designed the principles of intelligence at Cambridge University are thought as the educational center of the thousands of students; relaxation and entertainment are no more, but thoughts are eternal there. In summary, the deeper level of meaning concerns with the eternal thoughts of Cambridge University.

\section{Theme: The Deepest Level of Meaning}

The deeper level of meaning creates the deepest level of meaning which is also called Theme and the third order meaning. Hasan (1985: 97) states that Theme is the deepest level of meaning in verbal art; it is what a text is about when dissociated from the particularities of that text. In its nature, the Theme of verbal art is very close to generalizations which can be viewed as a hypothesis about some aspect of the social life of man. Moreover, Hasan (1985: 54) adds that the deepest level of meaning is a meaning that arises from saying one thing and meaning another. In this poem, saying one thing (the eternal thoughts of Cambridge University) means another meaning (intelligence). In conclusion, the deepest level of meaning deals with intelligence.

\section{CONCLUSION}

The lexicogrammatical analysis produces semantic components and there are two kinds of semantic patterns such as automatized and foregrounded. On the one hand, the automatized pattern produces the automatized meaning, and in turn the automatized meaning produces subject matter. At the stratum of Verbalization, on the other hand, consistency of foregrounding makes some foregrounded patterns produce consistently foregrounded meaning which is also called the deep level of meaning and the first order meaning. At the stratum of symbolic articulation, the deep level of meaning functions as symbol, sign or metaphor of the deeper level of meaning which is also called the second order meaning and literary meaning. At the stratum of Theme, the deeper level of meaning creates the deepest level of meaning which is also called Theme and the third order meaning. In summary, there is a systematic relation between lexicogrammar and Theme in verbal art. Then the meanings in the poem are outlined in the following table.

Table 8 Meanings of Verbal Art Semiotics

\begin{tabular}{|c|c|c|}
\hline Verbalization & Symbolic Articulation & Theme \\
\hline $\begin{array}{c}\text { Consistenly } \\
\text { Foregrounded Meaning }\end{array}$ & Literary Meaning & Theme \\
\hline $\begin{array}{l}\text { The Deep Level } \\
\text { of Meaning }\end{array}$ & $\begin{array}{l}\text { The Deeper Level } \\
\text { of Meaning }\end{array}$ & $\begin{array}{c}\text { The Deepest Level } \\
\text { of Meaning }\end{array}$ \\
\hline $\begin{array}{c}\text { The First } \\
\text { Order Meaning }\end{array}$ & $\begin{array}{l}\text { The Second } \\
\text { Order Meaning }\end{array}$ & $\begin{array}{l}\text { The Third } \\
\text { Order Meaning }\end{array}$ \\
\hline
\end{tabular}




\section{REFERENCES}

Butt, David. 1988. "Randomness, Order and the Latent Patterning of Text" in David Birch and Michael O’ Toole (eds.) Functions of Style. London: Pinter Publishers.

Butt, David. et al. 1995. Using Functional Grammar. Sydney: Macquarie University.

Eggins, Suzanna. 1994. An Introduction to Systemic Functional Linguistics. London: Pinter Publishers.

Halliday, MAK and Ruqaiya Hasan. 1985. Language, Context, and Text: Aspects of language in a social-semiotic perspective. Melbourne: Deakin University Press.

Halliday, MAK. 1993. Language as a Social Semiotic. London: Edward Arnold.

Halliday, MAK \& Christian Matthiessen. 1999. Construing Experience through Meaning:a LanguageBased Approach to Cognition. Berlin: de Gruyter.

Hasan, Ruqaiya. 1985. Linguistics, Language and Verbal Art. Melbourne: Deakin University Press.

Hasan, Ruqaiya. 1988. "The Analysis of One Poem: Theoretical Issues in Practice" in David Birch and Michael O Toole (eds.) Functions of Style. London: Pinter Publishers.

Hasan, Ruqaiya. 1996. "On Teaching Literature Across Cultural Distances" in Joyce E. James Ed. The Language-Culture Connection. Anthology series 37. Singapore: Seameo Regional Language Center

Martin, J.R. 1985. "Process and Text: Two Aspects of Semiosis" in Benson and Graves (eds.) Systemic Perspectives on Discourse. Norwood, New Jersey: Ablex.

Martin, J.R. 1992. English Text System and Structure. Amsterdam: John Benjamins Publishing.

Mukarovsky, Jan. 1977. The Word and Verbal Art. tr. J. Burbank and P. Steiner. New Haven: Yale University Press.

Matthiessen, Christian. 1995. Lexicogrammatical Cartography: English Systems. Tokyo, Taipei, Dallas: International Language Sciences Publishers.

Pradopo, R.D. 1996. Pengkajian Puisi. Jogjakarta: Gajah Mada University Press.

Preminger, A. 1974. Princeton Encyclopaedia of Poetry and Poetics. Princeton: Princeton University Press.

Plum, G.A. 1988. Text and Contextual Conditioning in Spoken English: A Genre Based Approach. Unpublished PhD Thesis. Sydney, Australia: University of Sydney. 